and practice of introducing media and information literacy into teacher education. The aim of the program is to support teachers in mastering of the competences of media and information literacy for the development and implementation of curriculum for school. The conceptual basis of the Media and Information Literacy Curriculum has three broad components of media and information literacy: text creation, text and audience. The Media and Information Literacy Curriculum contains eleven modules that cover key topics and issues of modern media. The modules of Curriculum can be integrated into courses or can be used in separate course on media and information literacy.

Key words: information literacy, media literacy, information competence, media competence, competence, curriculum, media and information literacy curriculum, UNESCO, teachers.

удк 371.1.07:371.5:373.1

\author{
Валентина Сокаль \\ Національний університет водного \\ господарства та природокористування \\ ORCID ID 0000-0003-0243-4542
}

Лариса Гурінчук

Городищенська загальноосвітня школа

I-III ступенів Березнівського р-ну Рівненської обл.

ORCID ID 0000-0001-6472-8701

DOI 10.24139/2312-5993/2020.01/103-115

\title{
УПРАВЛІННЯ РОЗВИТКОМ КРЕАТИВНОГО ЗАКЛАДУ ЗАГАЛЬНОЇ СЕРЕДНЬОÏ ОСВІТИ
}

Метою дослідження $\epsilon$ узагальнення досвіду управлінської та освітньої діяльності креативного закладу загальної середньої освіти відповідно до нововведень у системі освіти. Матеріали й методи дослідження: теоретичні (аналіз фрілософської, педагогічної, психологічної літератури) з метою обгрунтування вихідних положень дослідження; вивчення законодавчої бази стосовно діяльності закладу загальної середньої освіти, аналіз, систематизації та узагальнення досвіду роботи освітнього закладу; емпіричні: спостереження за освітнім процесом, моделювання діяльності закладу загальної середньої освіти, прогнозування перспектив розвитку закладу освіти. Результати дослідження. Визначено особливості педагогічних стратегій управління інформаційним розвитку освітнього закладу, науково обгрунтовано шляхи розвитку креативного закладу загальної середньої освіти відповідно до нового Закону України «Про освіту», достовірність дослідження забезпечено експертизою отриманих результатів. Наголошено на практичній необхідності залучення до дослідницької діяльності широкого кола педагогічних працівників та узагальнення досвіду щодо використання інновачійних технологій у розвитку творчого потенціалу учнів.

Ключові слова: заклад загальної середньої освіти, школа, педагогічні стратегії, креативність, інформаційний простір, управління, педагогічний вплив, досвід роботи.

Постановка проблеми. Поступове перетворення України на європейську, соціально орієнтовану, демократичну країну визначили 
значні зміни в шкільній освіті, її мету, завдання, креативні методи діяльності й управління закладом загальної середньої освіти.

Створення нової української школи, у якій учень має спроектувати власний майбутній життєвий шлях відповідно до своїх потенційних можливостей і творчих здібностей спонукає учнів займатися самовихованням, саморозвитком і самоосвітою. У цих умовах особливого значення набуває здатність особистості до нестандартного творчого мислення, вміння найефективніше вирішувати складні життєві ситуації та ухвалювати адекватні рішення, тобто формування креативної учнівської молоді.

Вважаємо, що такі якості в учнів можуть сформуватись у процесі діяльності закладу загальної середньої освіти, який і сам є креативним, у якому управлінська діяльність здійснюється на основі принципів демократизму, толерантності й поваги до всіх учасників освітнього процесу, у якому адміністрація школи постійно творчо працює 3 учнівським, педагогічним, батьківським колективами та громадськістю через використання сучасних інноваційних та інформаційних технологій.

Аналіз актуальних досліджень. Концепція сучасної креативної освіти підкріплена основними документами, що забезпечують діяльність освітньої галузі це: Закони України «Про освіту» та «Про загальну середню освіту», Національна доктрина розвитку освіти України, Загальна декларація прав людини, Декларація прав дитини та інші документи, в яких розглядаються питання реформування сучасної освіти тощо.

Дослідженнями різних аспектів проблеми креативності, творчості, креативної освіти займалися багато науковців. Філософські витоки креативності досліджували такі вчені, як М. Бердяєв, Г.Гегель, І. Кант, П. Лезін, В. Соловйов, Л. Фейєрбах, Ф. Шеллінг. У психології - це обґрунтування понять «креативність», «творчість», «творча діяльність», «творча активність», «творчий потенціал» (Д. Богоявленська, Л. Бурлачук, Л. Виготський, І. Волков, В. Козленко, О. Леонтьєв, А.Маслоу, С. Сисоєва та ін.). Значний вклад у розуміння філософських засад креативності внесли представники української філософської школи (Г. Сковорода, І.Я. Франко та ін.).

Метою нашого дослідження $є$ узагальнення досвіду управлінської та освітньої діяльності креативного закладу загальної середньої освіти відповідно до нововведень у системі освіти. Для реалізації мети в роботі поставлено такі завдання: проаналізувати управлінські рішення керівника закладу загальної середньої освіти, виявити найбільш ефективні методи та прийоми впровадження інноваційних технологій в управління освітнім закладом, описати модель креативного закладу загальної середньої освіти.

Виклад основного матеріалу. Сучасні вимоги до шкільної освіти потребують високої професійної компетентності всіх учасників освітнього процесу й керівників закладів загальної середньої освіти зокрема. Нововведення в системі сучасної освіти України, створення нової 
української школи потребують використання ефективних, інноваційних підходів до управління закладами освіти, зокрема закладами загальної середньої освіти. У закладі загальної середньої освіти мають бути розвинені та педагогічно скориговані творчі можливості, закладені в кожній людині природою. Школа повинна сприяти розвиткові творчого потенціалу особистості кожного учня, допомогти школярам визначитись у майбутній професійній діяльності. Вдалий вибір професії випускниками та їх життєва самореалізація $€$ показником ефективної діяльності закладу загальної середньої освіти.

Відомий науковець Л. Ващенко визначає креативну освіту як:

- спрямовану на розвиток загальної креативності учасників педагогічного процесу;

- освіту з гнучкою системою форм організації освітнього процесу відповідно до здібностей, нахилів, потреб учнів;

- зорієнтовану на використання інноваційних педагогічних технологій, що забезпечують особистісне зростання та розвиток творчого потенціалу учнів (Ващенко, 2005, с. 34).

Дослідження проведені науковцями свідчать про те, що креативність $\epsilon$ найважливішою навичкою, що допомагає підготувати особистість до викликів сучасного суспільства.

Креативну освіту О.Артемова визначає як освіту, спрямовану на розвиток загальної креативності учасників педагогічного процесу, освіту 3 гнучкою системою форм організації навчально-виховного процесу відповідно до здібностей, нахилів, потреб особистості (Артемова, 2017, с. 149).

На основі аналізу психолого-педагогічної літератури та власного досвіду ми вважаємо, що креативна освіта спрямована на розвиток творчого інтелектуального потенціалу всіх учасників освітнього процесу. Окрім того, креативна освіта зорієнтована на використання інноваційних педагогічних технологій, системно використовує соціальний, науковий, і педагогічний потенціал регіону.

Підготовка соціально адаптованого випускника вимагає від сучасної школи докорінного переосмислення й пошуку шляхів удосконалення освітнього процесу. У такому ракурсі для досягнення мети та якості надання освітніх послуг необхідно, насамперед, модернізувати управлінську діяльність у закладі освіти.

Педагогічний колектив Городищенської загальноосвітньої школи I-III ступенів Березнівської районної ради шукає відповіді на ключові питання: як зробити заклад загальної середньої освіти комфортним для кожного учня, привабливим для батьків, творчим майданчиком для вчителя. Так з'явилась ідея побудови креативного закладу загальної середньої освіти, що орієнтується на неоднорідність контингенту («школа для всіх», «школа рівних можливостей»), на поліпрофільність освіти з урахуванням творчих здібностей 
учнів і потреб суспільства. Відповідно, виникла необхідність у створенні моделі управління, яка б адекватно реагувала на інноваційні зміни.

3 цією метою розроблено модель креативної Городищенської загальноосвітньої школи І-ІІІ ступенів, у якій визначено основну місію школи: навчити дитину жити, перетворити знання на життєву компетенцію учнів, на розширення їх індивідуальних ресурсів, підготувати конкурентоспроможного випускника школи.

У нашому закладі загальної середньої освіти панує тверде переконання, що кожен учень - це унікальна й неповторна особистість. Тому пріоритет вільного розвитку дитини $є$ базовим принципом побудови управлінської діяльності. Створена й діє цільова програма адаптивного управління, яка передбачає перехід в управлінській діяльності від традиційного до креативного управління, що ґрунтується на заснуванні стратегії розвитку, сприяє розкриттю та реалізації особистісного потенціалу всіх учасників освітнього процесу. 3 цією метою використовуються інноваційні технології управління: - громадсько-державне; - особистісно зорієнтоване; - управління інноваційними проєктами (Паращенко, 2011, с. 236).

Особлива увага приділяється принципу особистісно зорієнтованого управління школою: персоналізація внеску кожного в спільну діяльність, особистість підлеглого розглядається як рівноправний суб'єкт управлінського процесу, усвідомлення індивідуальних внесків у спільну справу, створення ситуації успіху.

Щорічно в школі проводяться: конкурси методичних проєктів «€ ідея», «Від атестації до атестації», «Учитель року», «Конкурс-ярмарок педагогічної творчості», «А я роблю це так» тощо; презентації роботи вчителів; конкурси: «Кращий клас року», «Учень року», «Галерея визнання», «Олімпійська надія».

Педагогічний колектив школи працює над реалізацією проблемного питання «Реалізація сучасних підходів до навчання та виховання компетентної особистості в умовах інтеграції до європейського освітнього простору», метою якого визначено розробку, теоретичне обґрунтування та експериментальну перевірку динамічної моделі зростання компетентності особистості й вироблення практичних рекомендацій щодо вдосконалення змісту, форм і методів методичної роботи.

Розроблено й апробуються освітні проекти, у яких віддзеркалюються пріоритетні напрями розвитку закладу загальної середньої освіти: «Впровадження ІКТ в освітній процес», «Програма профільного навчання та до профільної підготовки», експериментальна програма «Здоров'ятко», шкільна програма «Обдарованість», «Цільова творча програма превентивного виховання».

Ефективно працює консалтинг-центр. Метою діяльності центру $\epsilon$ створення бази даних щодо впровадження освітніх педагогічних 
технологій, збір і трансформація інформації, підготовка й експертиза проєктів, висвітлення роботи шкільного колективу.

Внутрішнє шкільне управління базується на використанні системи моніторингу освітнього процесу закладу освіти, що забезпечує включення в процес підготовки та прийняття управлінських рішень усіх суб'єктів освітнього процесу, а також удосконалення технології управління школою.

Програма розвитку школи розроблена на підставі сучасних нормативно-правових актів та законодавства України (Закон України «Про освіту»; Навчальні програми для 10-11 класів; Паращенко, 2011; Стандарти освіти; Нова українська школа). Схвалена радою школи й затверджена зборами трудового колективу, вона містить далекі та близькі прогнози діяльності закладу освіти, що орієнтовані на модель випускника, характерними рисами якого $\epsilon$ : життєве самоствердження й самореалізація, забезпечення життєвого успіху завдяки наполегливій праці, володіння мистецтвом спілкування.

Провідні ідеї відображають пріоритети розвитку школи: упровадження компетентнісно орієнтованого підходу в освіті як основи формування життєспроможної самодостатньої особистості; організація профільного навчання; запровадження новітніх інформаційно-комунікаційних технологій у освітній процес; упровадження моніторингу якості освіти учнів у контексті зовнішнього незалежного оцінювання, створення освітнього округу. Усе це знайшло конкретне втілення в перспективних заходах щодо реалізації програми розвитку закладу освіти, в інноваційних проєктах, цільових програмах, програмах педагогічних досліджень, річних планах роботи школи.

Конкретні заходи розроблено щодо реалізації Національної стратегії розвитку освіти в Україні на період до 2021 року (2013), Державного стандарту базової і повної загальної середньої освіти (2011), Критеріїв оцінювання навчальних досягнень учнів (2011), Концепції «Нова українська школа» (2017), які адаптовані до учнів школи, а також передбачені в перспективних заходах розвитку школи.

Усі перспективи розвитку закладу сплановані реально, конкретно, на підставі глибокого аналізу стану освітнього процесу, а головне управлінської діяльності школи. Особливістю Програми є прогнозування очікуваних результатів за всіма напрямами освітньої діяльності: створення в школі цілісного освітнього середовища, яке надасть широкі можливості кожному учневі реалізувати власні освітні потреби й забезпечить безперервність освіти; становлення компетентнісно спрямованого освітнього процесу; формування в молоді національної свідомості; формування життєвої компетентності учнів; створення умов для використання новітніх освітніх технологій і підвищення педагогічної майстерності вчителів; упровадження високих освітніх стандартів із метою інтеграції випускників школи в освітні простори; проведення зовнішнього 
незалежного оцінювання й удосконалення управлінської діяльності на основі інноваційних педагогічних технологій.

Планування роботи закладу загальної середньої освіти вимагає серйозного опрацювання нормативних і концептуальних документів розвитку системи освіти в Україні (Закон України «Про освіту», 2017; Національної стратегії розвитку освіти в Україні на період до 2021 року, 2013; Державного стандарту базової і повної загальної середньої освіти, 2011; Типової освітньої програми закладів загальної середньої освіти III ступеня, 2018; Концепції «Нова українська школа», 2017), порівняльного аналізу перспективного вітчизняного досвіду управління в нових соціально-економічних і політичних умовах (Ващенко, 2005; Паращенко, 2011; Мартинець, 2018).

Усі плани утілюють конкретні дії педагогічного колективу, спрямовані на реалізацію концепції закладу освіти, провідною ідеєю якої $\epsilon$ забезпечення рівного доступу до якісної освіти кожному учневі як основи формування особистості, орієнтованої на досягнення успіху в різних сферах діяльності.

Перспективний план роботи уточнює й конкретизує розвиток школи з усіх напрямів: упровадження моделі навчання й виховання, реалізація цільових програм «Цільова творча програма превентивного виховання учнівської молоді», «Цільова творча програма формування здорового способу життя» розроблені й упроваджені педагогічним колективом Городищенської ЗОШ І-ІІІ ступенів.

Поетапно вдосконалюється система роботи з реалізації особистісно орієнтованого підходу до розвитку дитини на основі інноваційних технологій, моніторингових досліджень: створюються умови для виховання творчо розвиненої особистості, виховання громадянської та національної свідомості учнів.

Таким чином, перспективний план внутрішнього шкільного контролю передбачає основні об'єкти й напрями контрольно-аналітичної діяльності на п'ять років, у тому числі атестацію педагогічних кадрів, курсову перепідготовку, вивчення стану викладання основ наук, мета яких удосконалення якості навчання.

Річний план роботи закладу загальної середньої освіти протягом останніх років має декілька модифікацій, метою створення яких є пошук оптимальної структури та змісту. У річному плані чітко визначено проблему й головні завдання, над якими працює школа. Річний план передбачає конкретні управлінські дії, спрямовані на реалізацію концептуальних прогнозів розвитку школи. Головними завданнями педагогічного колективу $\epsilon$ : удосконалення його роботи зі збереження шкільного контингенту й виконання закону України «Про освіту» (2017), забезпечення безперервності освітнього процесу, орієнтованого на 
індивідуальний розвиток особистості школяра; реалізація компетентнісно орієнтованого підходу до навчання й виховання через відновлення змісту освіти, упровадження інтерактивних технологій на всіх ступенях навчання; підвищення мотивацій учительського й учнівського колективів до творчого розвитку й самоосвітньої діяльності; удосконалення системи контролю за навчальними досягненнями учнів через моніторингову систему; удосконалення інформаційно-аналітичної системи керування на новій концептуальній основі; створення належних умов для охорони праці.

Усі проблемні рішення, прийняті педагогічною радою, допомагають скорегувати роботу педагогічного колективу школи, направити її на рішення проблем, які диктує сьогодення, на вдосконалення освітнього процесу.

Робота над проблематикою закладу загальної середньої освіти реалізується через інноваційні та традиційні форми роботи: методичні об'єднання, проблемні семінари, відкриті уроки, предметні тижні, семінари-практикуми, ділові й рольові ігри, тренінги, тижні майстерності, «круглі столи», творчі звіти вчителів, тижні молодих учителів тощо.

Робочий навчальний план, складений на підставі типового плану Міністерства освіти і науки України, має пояснювальну записку. Години інваріантної складової відповідають програмам із навчальних предметів; варіативна складова використовується 3 урахуванням освітніх запитів школярів і їхніх батьків (на підставі заяв). Особлива увага приділяється плануванню профільного навчання, в основі якого - бажання та здібності учнів, кадрове, програмно-методичне забезпечення та навчальноматеріальна база.

Значна увага приділяється оптимізації шкільного контингенту 1-х та 10-х класів: зарахування учнів проводиться на підставі заяв, копій свідоцтв про народження.

Планування роботи структурних підрозділів (виховної, календарнотематичне планування вихователів групи продовженого дня, публічношкільної бібліотеки, гуртків, секції) узгоджено із загальношкільним планом. Календарне планування 3 навчальних предметів відповідає вимогам навчальних програм, теми доцільно розбито за тематичним оцінюванням. Плани розглянуто на шкільних методичних об'єднаннях, затверджено директором. Стан поурочного планування постійно контролюється адміністрацією школи. Система планування в закладі загальної середньої освіти, спрямована на вирішення та реалізацію кінцевого результату підвищення якості освіти, формування творчого педагогічного колективу, здатного ефективно навчати, виховувати учнів і сприяти їхньому розвиткові.

Отже, у школі розроблено дієву технологію планування освітнього процесу на підставі аналітичної діяльності й моніторингової системи досліджень навчальних досягнень учнів з усіх предметів. 
Вироблення й ухвалення управлінських рішень - основна процедура в діяльності адміністрації школи, яка визначає весь подальший хід процесу управління, суттєво впливає на результати діяльності школи. У своїй практиці директор школи та його заступники застосовують такі технології прийняття рішень, які включають: діагностування проблеми, накопичення інформації, розробку альтернативних варіантів, їх оцінку й ухвалення управлінського рішення.

Працюючи над реалізацією педагогічної проблеми, директор та його заступники разом із керівниками методичних об'єднань розробили стратегію впровадження основних ідей досліджуваного питання, спрогнозували результати, причому з урахуванням демократичних принципів управління ці процеси делегувалися знизу (учитель - окружні та шкільні методоб'єднання - нарада при директорові - педрада).

Такий підхід до управління закладом загальної середньої освіти робить його системним, ефективним, дієвим, а рішення, що ухвалюються в ході реалізації поставлених завдань стають життєвими й доступними для сприймання й реалізації педагогічним колективом.

Стратегічне управління школою передбачає як визначення довгострокових цілей управлінського й педагогічного процесів, так і поступове здійснення суб'єктами управління управлінських рішень (Мартинець, 2018).

У школі створена інформаційна база з актуальних питань управління, яка постійно оновлюється. 3 цією метою адміністрація школи переглянула систему інформаційного забезпечення управління. Найбільш поширеними й ефективними формами управлінських рішень $є$ рішення педагогічної ради (обов'язково визначаються терміни й виконавці, розробляється система заходів; повідомлення про хід виконання їх рішень заслуховується на наступній педраді).

Наприклад, активізована робота щодо впровадження державногромадської моделі управління закладом загальної середньої освіти; у якій пріоритет у прийнятті стратегічних і тактичних рішень розвитку закладу освіти надається органові громадського самоврядування - загальношкільним зборам і раді школи, в складі якої є представники учнівського, батьківського й педагогічного колективів. Саме за рішенням загальних зборів було схвалено Програму розвитку закладу загальної середньої освіти.

Рада школи $€$ активним учасником підготовки щорічного звіту адміністрації школи перед батьківським комітетом і громадськістю, тобто реалізується принцип відкритості в діяльності закладу освіти. Під час звітування директор закладу загальної середньої освіти аналізує процес управлінської діяльності, ефективність ухвалення управлінських рішень, оприлюднює найважливіші результати діяльності школи: результати учнівських конкурсів, олімпіад, методичних доробок педагогічного колективу, рейтинг школи за результатами освітнього процесу, результати 
атестації, звіт про стан матеріально-технічної бази, фінансовий звіт тощо. Таким чином, принцип відкритості сприяє залученню до ухвалення управлінських рішень громадськості, що дає можливість удосконалити систему управлінської діяльності закладу загальної середньої освіти, допомагає ухвалювати управлінські рішення, які $\epsilon$ прозорими й відкритими для всіх учасників освітнього процесу.

Підвищення ефективності функціонування закладу загальної середньої освіти адміністрація й педагогічний колектив досягли завдяки впровадженню політики управління змінами (стратегічного управління освітнім закладом).

Адміністрація закладу загальної середньої освіти поступово впроваджує методику та способи адаптивного управління, що дає змогу активізувати самоаналіз і саморегуляцію діяльності вчителів завдяки використанню аналітичної, педагогічної та професійної діяльності.

Учителі проводять самоаналіз своєї діяльності двічі: за рік до планової атестації та безпосередньо через атестацію (жовтень або березень). Адміністрація проводить експертизу їхнього професійного зростання, порівнюючи діаграми, побудовані комп'ютерною програмою.

У закладі загальної середньої освіти активно впроваджуються інтерактивні технології, у тому числі в управлінській діяльності. Інтерактивні технології застосовуються в різних формах організації управлінського процесу (нарадах, зборах, засіданнях). Стало традиційним проведення засідань педагогічних рад із використанням таких технологій, як: робота в малих групах, мозковий штурм, «ажурна пилка», групове інтерв'ю, групові дискусії, метод-прес, а також технології «навчаючи, вчуся» та елементів тренінгу тощо.

В арсеналі інноваційних управлінських технологій, які ми впроваджуємо, $€$ й проєктні технології. Проєктні технології також використано під час розробки шкільної «Програми формування здорового способу життя», екологічного проєкту «Екологія і ми» та ін.

Оновлення школи неминуче потребує внесення інноваційних змін і в організаційну структуру. Адміністрація закладу загальної середньої освіти вбачає організаційний розвиток насамперед через покращення комунікації між членами педагогічного колективу й духовний професійний розвиток педагогів. Максимальна кількість управлінських функцій має передаватися тим співробітникам, які найбільш здатні до самоосвіти й саморозвитку. Тому в школі ефективно працює рада школи, методична рада. До управлінської діяльності залучені керівники методичних об'єднань, творчих груп, тимчасових груп тощо. Створюються тимчасові групи, що виконують певні завдання з реалізації шкільних проєктів. Керівник закладу надає таким групам повноваження щодо ухвалення 
оперативних рішень у межах виконуваних завдань і водночас покладає на них відповідальність за досягнення очікуваних результатів.

У практику роботи закладу загальної середньої освіти впроваджено технологію колективного ухвалення управлінських рішень, яка суттєво впливає на результати діяльності школи та її імідж.

Інновацією в управлінні також $€$ впровадження інформаційних технологій - комп'ютерна програма, що включає директивні й нормативні документи державних органів, у тому числі Міністерства освіти і науки України Кабінету Міністрів тощо. У кабінеті директора $є$ також і картотека директивних і нормативних документів органів управління освіти, а самі документи знаходяться в методичному кабінеті школи. Педагогічні працівники постійно ознайомлюються з директивними документами на інструктивно-методичних нарадах.

у методичному кабінеті та кабінеті виховної роботи зібрані матеріали, що надають інформацію про роботу педагогічних працівників, рівень навчальних досягнень учнів, роботу з батьками та громадськістю, про стан відвідування учнями навчальних занять, методичну роботу тощо. Методичний кабінет Городищенської ЗОШ I-ІІІ ступенів $\epsilon$ переможцем конкурсу методичних кабінетів Березнівського району.

Серед пріоритетних завдань розвитку освіти в Україні, визначених Національною стратегією розвитку освіти в Україні на період до 2021 року (2013), яка схвалена Всеукраїнським з'їздом працівників освіти України, $\epsilon$ охоплення навчанням і вихованням усіх дітей, забезпечення кожному школяреві доступу до якісної освіти, економічних і соціальних гарантій для професійної самореалізації педагогічних працівників та розвитку матеріально-технічної бази освіти.

Одним із засобів вирішення цих завдань $є$ запровадження освітніх округів. Це прояв нового підходу до розвитку й управління середньою освітою на місцевому рівні, тому що будуть створені оптимальні умови для функціонування й розвитку закладів освіти, у яких буде врахований регіональний і територіальний фактори.

Головною метою створення таких округів $\epsilon$ формування єдиного освітнього простору в межах адміністративно-територіальної одиниці та належних умов для забезпечення освітнього процесу, реалізації програми до профільного та профільного навчання, розвитку обдарованості, творчих здібностей і нахилів учнів та впровадження в освітній процес сучасних інтерактивних і креативних технологій. Успішна діяльність освітніх округів допоможе сформувати високий інтелектуальний людський потенціал, що, у свою чергу, сприятиме соціально-економічному розвиткові територіальної одиниці.

У школі розроблено й утілено в життя проєкт «Соціально активна школа», що призвело до створення сприятливих соціально-психологічних, 
психолого-педагогічних і професійно-особистісних умов для підвищення рівня соціалізації учнівської молоді на засадах активізації креативного й інтелектуального потенціалів. Ефективними в межах проєкту були тренінги: «Виборча кампанія», «Інтерактивні методи в роботі з молоддю», «ВІЛ/СНІД: стигма та дискримінація», «Зроби Європу своїми руками», у яких учні набували навичок здорового способу житт, толерантного ставлення до людей, дізнавалися про права людини та про особливості виборчого законодавства.

При школі діє центр інтерактивних оцінювань для вивчення громадської думки. 3 метою вивчення стану адаптації учнів до освітнього процесу постійно проводиться анкетування «Школа очима учнів» і «Школа очима батьків», а також тестування учнів 1-х і 5-х класів психологом школи.

3 метою виявлення рівня задоволеності батьків роботою освітнього закладу з батьками учнів школи було проведено анкетування (за методикою Є.М. Степанова). Результати анкетування підтвердили, що педагогічний колектив працює добросовісно, креативно, інтерактивно застосовує нові освітні технології, діяльність закладу загальної середньої освіти є відкритою - 87,6\% батьків задоволені якістю надання освітніх послуг і роботою педагогічного колективу школи.

Висновки. Таким чином, зазначимо, що завдяки ефективному управлінню закладом загальної середньої освіти, активізувалася творча діяльність і педагогічного, і учнівського колективів. Також підвищився рівень педагогічної майстерності та психолого-педагогічної культури всіх педагогів школи. У практику діяльності закладу загальної середньої освіти впроваджено інноваційні технології, які відповідають сучасним змінам у освіті, зокрема реалізації завдань нової української школи та спрямовані на розвиток креативності учасників освітнього процесу. Значно підвищилася якість надання освітніх послуг, про що свідчать результати анкетування батьків. Удосконалено систему психолого-педагогічного супроводу розвитку особистості учня, що забезпечує максимально сприятливі умови для розвитку свідомості й самосвідомості школярів, самореалізації кожного учня у творчому середовищі.

Перспективи подальших досліджень вбачаємо в дослідженні розвитку закладів загальної середньої освіти в територіальних громадах.

\section{ЛІТЕРАТУРА}

Артемова, О. І. (2017). Психологічні та педагогічні креативні технології у професійній підготовці вчителя початкових класів. Оновлення змісту, форм та методів навчання і виховання в закладах освіти, 15 (58), 148-151. (Artemova, О. I. (2017). Psychological and pedagogical creative technologies in vocational training of elementary school teachers. Updating the content, forms and methods of education and upbringing in educational institutions, 15 (58), 148-151). 
Ващенко, Л. М. (2005). Управління інноваційними процесами в загальній середній освіті регіону. К.: ВПЦ «Тираж». (Vashchenko, L. М. (2005). Management of innovation processes in general secondary education in the region. K.: TPC "Circulation").

Закон України «Про освіту» МОН України від 05.09.2017 № 2145-VIII. Режим доступу: https://zakon.rada.gov.ua/laws/main/2145-19 (Law of Ukraine "On Education" Ministry of Education and Science of Ukraine dated 05.09.2017 № 2145-VIII. Retrieved from: https://zakon.rada.gov.ua/laws/main/2145-19).

Мартинець, Л. А. (2018). Управлінська діяльність керівника навчального закладу. Вінниця. (Martynets, L. A. (2018). Management activity of the head of the educational institution. Vinnitsa).

Навчальні програми для 10-11 класів. Режим доступу: https://mon.gov.ua/ua/osvita/zagalna-serednya-osvita/navchalniprogrami/navchalni-programi-dlya-10-11-klasiv (Curricula for grades 10-11. Retrieved from: https://mon.gov.ua/ua/osvita/zagalna-serednya-osvita/navchalniprogrami/navchalni-programi-dlya-10-11-klasiv).

Національна стратегія розвитку освіти в Україні на період до 2021 року, схвалена Указом Президента України від 25.-6.2013 № 344/2013. Режим доступу: www.president.gov.ua /documents/ 15828.html. (National Strategy for the Development of Education in Ukraine for the Period up to 2021, approved by the Decree of the President of Ukraine of 25.6.2013 № 344/2013. Retrieved from: www.president.gov.ua / documents/ 15828.html.)

Паращенко, Л. І. (2011). Державне управління розвитком загальної середньої освіти в Україні: методології, стратегії, механізми. K.: Майстер книг. (Paraschenko, L. I., (2011). Public administration of general secondary education in Ukraine: methodologies, strategies, mechanisms. K.: Book M aster).

стандарти освіти. Режим доступу: https://mon.gov.ua/ua/osvita; https://xn-80aagahqwyibe8an.com/zakon-ukrajiny/stattya-standarti-osviti-325772.html

(Education standards. Retrieved from: https://mon.gov.ua/ua/osvita; https://xn-80aagahqwyibe8an.com/zakon-ukrajiny/stattya-standarti-osviti-325772.html.

Нова українська школа. Концептуальні засади реформування середньої школи. Режим доступу: https://www.kmu.gov.ua/storage/app/media/reforms/ukrainska-shkolacompressed.pdf (New Ukrainian School. Conceptual principles of secondary school reform. Retrieved from: https:// www.kmu.gov.ua/storage/app/media/reforms/ukrainska-shkolacompressed.pdf

Типова освітня програма закладів загальної середньої освіти III ступеня. Режим доступу: https://zakon.rada.gov.ua/rada/show/ru/v0406729-18 (Typical educational program of general secondary education institutions of III degree. Retrieved from: https://zakon.rada.gov.ua/rada/show/ru/v0406729-18)

\section{PEЗЮME}

Сокаль В. А., Гуринчук Л. Е. Управление развитием креативного учреждения общего среднего образования.

Целью исследования является обобщение опыта управленческой и образовательной деятельности креативного учреждения в соответствии с нововведениями в системе общего среднего образования. Материалы и методы исследования: теоретические - анализ, систематизация и обобщение опыта работы учебного заведения; эмпирические: наблюдение за образовательным 
процессом, моделирование образовательной деятельности учреждения общего среднего образования, прогнозирования перспектив развития учебного заведения. Результаты исследования. Определены особенности педагогических стратегий управления информационным развитием учреждения, научно обоснованы пути развития креативного учреждения общего среднего образования в соответствии с новым Законом Украины «Об образовании», достоверность исследования обеспечена экспертизой полученных результатов. Отмечена практическая необходимость привлечения к исследовательской деятельности широкого круга педагогов и обобщение опыта использования инновационных технологий в развитии творческого потенциала учащихся.

Ключевые слова: общеобразовательная школа, педагогические стратегии, креативность, информационное пространство, управление, педагогическое воздействие, опыт работы.

\section{SUMMARY}

Sokal Valentyna, Gurinduk Larysa. Managing development of a creative institution of general secondary education.

The purpose of the study is to summarize the experience of management and educational activities of a creative institution of general secondary education in accordance with innovations in the education system. Materials and methods of research: theoretical (analysis of philosophical, pedagogical, psychological literature) in order to substantiate the initial provisions of the study; study of the legislative base regarding the activity of the general secondary education institution, analysis, systematization and generalization of the education institution's work experience; empirical: observing the educational process, modeling the activity of a general secondary education institution, forecasting the prospects for the development of an education institution. The results of the study: the features of pedagogical strategies for managing the institution's information development are identified, the ways of developing a creative education institution in accordance with the new Law of Ukraine "On Education" are scientifically substantiated, the reliability of the study is ensured by the examination of the results. The practical necessity of attracting a wide circle of teachers to research activities and generalization of the experience of using innovative technologies in the development of students' creative potential is noted. Of particular importance in the current context of educational development is the issue of forming a creative personality capable of creative thinking, able to solve effectively complex problems of their own lives and make appropriate decisions.

Creation of a new Ukrainian school in which a student should design his or her future life path in accordance with his potential and creative abilities encourages students to engage in self-development and self-education. In these conditions, the ability of the individual to non-standard creative thinking, the ability to most effectively solve difficult life situations and make adequate decisions, that is, formation of creative youth, becomes particularly important.

We believe that such qualities of students can be formed in the process of activity of the institution of general secondary education, which itself is creative, in which the management activity is carried out on the principles of democracy, tolerance and respect for all participants of the educational process, in which school administration constantly works creatively with students, pedagogical, parental teams and the public through the use of modern innovative and information technologies.

Key words: institution of general secondary education, pedagogical strategies, creativity, information space, management, pedagogical impact, work experience. 